\title{
Oral Reconstituted Suspension Dosage
}

\section{Form}

National Cancer Institute

\section{Source}

National Cancer Institute. Oral Reconstituted Suspension Dosage Form. NCI Thesaurus.

Code C68981.

A suspension composed of active and/or inert ing redient(s) that requires reconstitution and is intended oral administration. 